\title{
INTERNET ADDICTION AMONG MADRASAH ALIYAH STUDENTS
}

\author{
Nursalamah Siagian \\ Balai Penelitian dan Pengembangan Agama Jakarta \\ Jl. Rawa Kuning No. 6 Pulo gebang, Cakung, Jakarta Timur \\ Email:salamah.siagian@gmail.com \\ Nur Alia \\ Puslitbang Pendidikan Agama dan Keagamaan \\ $J$ MH. Thamrin no.6 Jakarta Pusat \\ Email: alia.litbang@gmail.com
}

Article received August 5 $5^{\text {th }}, 2021$; Article revised September 19 $9^{\text {th }}, 2021$; Article approved October 22 $2^{\text {th }}, 2021$

\begin{abstract}
The entry of new technology, the Internet, in people's lives demands adaptation by various groups, including students. With the use of the Internet by students, there will be changes in their lifestyle, which can affect their activities at school. This study focused on the intensity of internet use by students at Madrasah Aliyah (MA) Al Islamiyah Depok City, which then tend to become addicted to the Internet. This study used interview techniques, and the respondents were the Principal of Madrasah, teachers, and students. Document studies were also used to analyze case reports on internet use recorded by Guidance Counseling (BK) teachers. This study also used a questionnaire distributed online to 340 students at MA Al-Islamiyah Depok City. This study found that 14\% of students access the Internet for more than 9 hours, $29 \%$ of students feel uncomfortable if they are not connected to the Internet, and 54\% of respondents feel anxious if they run out of the internet quota, so they will immediately buy the quota. The impact of using the Internet intensively is that students are lazy to do other activities, such as playing with peers and forget about their duties and responsibilities, particularly studying. In addition, even when studying in class, they still use cell phones for social media and listening to music.
\end{abstract}

Keywords: internet addiction, madrasah aliyah al-islamiyah, social media

\section{INTRODUCTION}

$\mathrm{T}$ oday, the Internet has become an essential part of life and even become the daily needs of most individuals. The Internet can be accessed easily anywhere and anytime to communicate and interact with other people (Dewi, 2016:221). Inevitably, the Internet as a technology that facilitates human life also has a negative impact. Excessive internet use can result from social contacts when individuals spend more time using the Internet than directly interacting with family and friends. This will lead individuals to smaller social circles, resulting in higher levels of loneliness and stress (Indra, 2019:2). In physical health, the impacts include reduced sleep time, excessive fatigue, lowered immune system, lack of exercise, low self-hygiene, and eye and back muscle tension. Meanwhile, other impacts, especially for students, are declining grades, not attending class, refusing study habits, and other problems such as cyberbullying, sexual predators, and being exposed to pornography (Nurfadhilah, 2016).

Adolescent addiction to the Internet has become a national concern that negatively impacts educational achievement and personality. Kompas stated at least 17 cases of children addicted to gadgets since 2013, which were handled by the Indonesian Child Protection Agency. The National Commission has also held 42 cases for Child Protection since 2016 (Kompas, 23 July 2018). Several hospitals also handled cases of gadget addiction. Koesnadi General Hospital, Bondowoso, East Java, since January 2018, has treated 11 junior high and high school students. Addiction Psychiatry Polyclinic, Cipto Mangunkusumo National Central General Hospital (RSCM), treated 18 students addicted to online games. A similar case occurred in Magelang; 28 children were also 
being treated at the Marsudi Putra Social Institution (PSMP) Antasena. The symptoms that appear are almost the same, including injuring yourself by banging your head against a wall and endangering your parents' lives when you are prohibited from using gadgets. Some of them even take drugs, such as methamphetamine and methamphetamine, to stay awake. Some children experience attention deficit disorders and become hyperactive in pre-school age children (Setianingsih, Amila Wahyuni, \& Firiana Noor, 2018).

Cases of youth addiction to the Internet as described above may be heard more often because of the rapid increase in internet users from year to year. Based on data obtained from the Association of Indonesian Internet Service Providers (APJII) in 2017, internet users in 2016 were 132.7 million. Then in 2017 , it increased to 143.26 million people from Indonesia's total population of 262 million people. These users come from various circles, including students who are still in high school / Madrasah Aliyah (MA). The internet user penetration is dominated by ages $13-18$ years with a range of $75.50 \%$, then ages $19-34$ years at $74.23 \%$, ages $35-54$ years at $44.06 \%$, and 54 and over at $15.72 \%$.

Meanwhile, based on the number of internet users in cities that support the nation's capital, Depok is one of the cities with high internet users. The Central Statistics Agency (BPS) of West Java in 2018 asserted that Depok City is the city with the highest internet usage rate, which is $70.43 \%$. This may be related to the policy of the Depok City Government, in this case, the Communication and Information Office (Diskominfo), which continues to strive to improve excellent service in utilizing information and communication technology by installing free hot spots in several areas in Depok City. There are at least 130 points where WiFi transmitting devices are placed in public and social facilities, such as parks, urban village offices, places of worship, and along the Margonda highway and the Depok City office centre.

In line with such a situation, several schools in Depok City also facilitate internet access for school residents or allow students to bring cell phones to school. One of them is MA Al-Islamiyah. Students are even allowed to bring cell phones into the classroom during teaching and learning activities. For this reason, researchers consider it necessary to conduct a study at the MA Al-Islamiyah.

This study aims to analyze the intensity of internet use, as has been done by other researchers, and to analyze the aspects of disorders that occur in line with internet use among students. Specifically, this paper shows students' addiction to the Internet through the following three questions: (a) how is the intensity of internet use among students of MA Al-Islamiyah Depok City?; (b) how can the Internet affect the psychological condition of students?; and (c) how to overcome students' addiction to the Internet?. These three questions are the main topics of discussion in this study.

This paper is based on an argument that the entry of new technology into people's lives changes the pattern of communication as a form of technological facilities and encourages adaptation to various groups, including students. With the use of the Internet by students, the lifestyle of teenagers also undergoes changes that have consequences in the students' activities as teenagers. The Internet can be a force that structures the cultural life of teenagers in the environment where they live.

\section{New Media}

The term "new media" is a definition that combines multimedia that is literally the convergence of text, sound, and images in the same medium that are closely related to the CD-ROM delivery system (Pratt, 2000). The term new media also refers to digital media objects, which according to Pitrik (2002), include interactivity and are distributed digitally using computers or other devices that are useful for saving time on disseminating information and can encourage the learning process. This term itself arises from technological developments that are accepted by the community, where the existence of new media has replaced the old media, particularly physical media, which in turn requires a transformation by media entities (Situmorang, 2012). Such new media uses internet technology to produce communication, cultural expressions, and ways of living everyday life. New media also can allow the presentation of more varied information such as additional photos and 
videos, which according to Nurkiman (2017), enables the public to participate through suggestions and criticisms of the government actively.

However, the new media can construct a solid and efficient social control, containing hidden indoctrination and manipulation techniques (Kellner, 1995). In addition, the use of new media can also lead to disruptive phenomena in society (Pawito, 2014). Its emergence can also lead to "dehumanization" as a result of the digital era faced by modern society (Lenta and Cormos, 2014), where new media and digital technology are always "double-faced and become opponents" and tend to see others as " less human" (Ngafifi, 2014). Dehumanization is also the result of the self-perception process that concludes a lack of humanity through behavioural observations and attributions taken from overt behaviour. Also, it appears through the information that continues to increase on the Internet that provides an excess of information. Individuals find it difficult to find valuable information (Maulana, 2016).

\section{Internet Addiction}

Internet addiction is a psychiatric disorder characterized by excessive or uncontrolled preoccupations, urges, or behaviours about computer use and internet access that cause disturbance or distress (Shaw and Black, 2008). Addiction is a compulsive behavior (Febriandari \& Nauli, 2016) with dependence and lack of control (Adi Prasetyo, Amir, \& Psi, 2017). Behavior can be categorized into an addictive behavior if the behavior cannot be controlled and can harm the concerned person (Ksetyaningsih, 2015). Internet addiction can also have a relatively significant negative impact on adolescents, such as anxiety, depression, decreased physical and mental health, interpersonal relationships, and reduced performance (Hakim et al., 2004 in Nuraini, 2019:2).

Excessive and continuous internet use can be categorized into Internet Addiction Disorder (IAD) (Basri, 2014 in Anggraeni, 2019). Such addiction is associated with everything related to the Internet, such as social networks, online games, and pornography. This can be observed when someone is glued to all electronic devices connected to the Internet, which results in wasted time spent browsing the Internet, making them indifferent to the environment. Research conducted by Greenfield (Nurfhadilah, 2014: 21-22) states that dependence on the Internet can reduce the ability to manage essential aspects of life due to increased preoccupation with using the Internet. Users begin to miss deadlines at work, spend little time with family, and slowly withdraw from their everyday routines. Along with the increase in addiction, users become happier playing online games, chatting with friends in cyberspace, or even gambling online. In addition, users become neglectful of family and friends due to too much time in front of the computer. A study conducted by the Stanford Institute for the Quantitative Study of Society found that internet use led to increased loneliness and decreased intensity of social relationships.

\section{Human-Digital Technology Relations}

The relationship between humans and technology is described by Septiarti (2017), that digital technology causes fundamental changes in society (Wijaya, 2016; Palupi, 2015), such as the transition of industrial society to a knowledge-based society (Wijaya, 2016) which in turn affects aspects of education and culture. The existence of technology in human life transforms human life at all levels of social class, which according to Palupi (2015), can change their mindset. Thus, children exposed to this kind of technology become digital natives who are happy to customize, collaborate, and personalize, which can make them innovators (Supratman, 2018). Technology can also improve the education system, such as increasing welfare (Wijaya, 2016). However, it is necessary to continue to develop the education system by prioritizing egalitarianism, equality, emancipation, and participation in the communication process (Arintina, 2019). In its development, the relationship between digital technology in human life has come to digitization. According to Wuryanta (2004), it can change the transfiguration of media and communication technology to involve the community in the spatialization process from placement to space and time restrictions. In 
addition, this digitization by digital technology can bring people into the close relationships between agents, structural procedures, and social practices as an interactive relationship that surrounds them (Wuryanta, 2004).

Through the relationship between them, technology leads to positive relationships, which can affect the development of cultural identities, contacts between individuals, cultural acculturation, and changes in working (Palupi, 2015). It includes the qualification of workers who are required to have substantial knowledge and analysis and skills in using computers and processing information through digital technology (Wijaya, 2016). Thus, the relationship between humans and digital technology, according to Melissa (2010), leads to both advancement and blur of existing media, which allows for user interaction and control. This interaction is categorized into two critical points, the control over the texts of culture and interaction on the capacity of the media to integrate into the media text (Melissa, 2010). However, the dominance of technology can create new thoughts, such as positivism, communism, and capitalism. It then makes dehumanization where humans are trapped in the designed structural system (Septiarti, 2017). In addition, digital technology also places humans in a paradoxical condition between the combination of social automation and individual autonomy, which impacts "auto modernity" (Alatas, 2014).

\section{RESEARCH METHOD}

This research was conducted at MA Al-Islamiyah, which is located in Depok City. The reason for choosing MA Al-Islamiyah was that Madrasah has a policy that allows students to bring cell phones into class.

The data of this study were obtained by using interview techniques to the Principal of Madrasah, Vice Principal of Education, Vice Principal of Curriculum, teachers, and students. In addition, observations were also made on the activities of students when they were in the Madrasah. Document studies were also used as an instrument to view case reports related to internet use as recorded by teachers, especially Guidance Counselling (BK) teachers. This study also used a questionnaire as an instrument distributed online to all 340 students of MA Al-Islamiyah Depok City. 246 of 340 questionnaires were obtained, which were suitable for the data analysis process. The distribution of the questionnaire was carried out to measure the intensity of internet use of students.

\section{DISCUSSION \\ Respondent Profile}

This research data was obtained by distributing online questionnaires to 340 students of MA Al-Islamiyah Depok City. 246 of 340 questionnaires were obtained, which were suitable for the data analysis process. The total number of students who filled out the questionnaire, as presented in Table 2., consists of 110 male respondents $(45 \%)$ and 136 female respondents (55\%). Most respondents are from class 11 , who are $40 \%$ (97 students), while the respondents in class XII become the second-largest group by $34 \%$ (84 students), and the respondents in class $\mathrm{X}$ are the third-largest group by $26 \% \quad(65$ students).

Most of the students, $78 \% \quad(192$ students), use one device to access the Internet, usually a cell phone. The respondents who use two devices are 17\% (41 students), while the respondents who use three devices are only $2 \%$ or 4 students. 9 students (4\%) of the respondents use other devices, such as computers, to access the Internet in their daily lives.

\begin{tabular}{|c|c|c|c|c|c|}
\hline \multirow{2}{*}{ Category } & & \multicolumn{2}{|c|}{ Gender } & \multirow[t]{2}{*}{ Total } & \\
\hline & & Male & Female & & \\
\hline \multirow[t]{3}{*}{ Class } & $\mathrm{X}$ & & 26 & 39 & 65 \\
\hline & XI & & 38 & 59 & 97 \\
\hline & XII & & 46 & 38 & 84 \\
\hline \multirow[t]{2}{*}{ Major } & IPA & & 40 & 71 & 111 \\
\hline & IPS & & 70 & 65 & 135 \\
\hline \multirow{4}{*}{$\begin{array}{l}\text { The Number } \\
\text { of Commonly } \\
\text { Used Devices }\end{array}$} & One device & & 85 & 107 & 192 \\
\hline & Two devices & & 18 & 23 & 41 \\
\hline & Three devices & & 3 & 1 & 4 \\
\hline & Others & & 4 & 5 & 9 \\
\hline \multirow[t]{3}{*}{ Ownership } & One & & 90 & 128 & 218 \\
\hline & Two & & 6 & 2 & 8 \\
\hline & None & & 14 & 6 & 20 \\
\hline Total & & 110 & 136 & 246 & \\
\hline
\end{tabular}

Table 1. Respondent Profile 
Although all respondents use gadgets, both cell phones and smartphones, they are not all private property in their daily lives. The majority of respondents (89\%), 218 students, have one device, and only $3 \%$ of respondents ( 8 students) claim to have 2 devices. Another $8 \%$ of respondents (20 students) admit that they do not have a smartphone, but they still use a gadget because it belongs to their parents or relatives. In addition, some students at MA Islamiyah live in Islamic boarding schools where having smartphones are not allowed, and there are also economic factors.

\section{The Intensity of Internet Use Among Students at MA Al-Islamiyah}

There are 28 Madrasah Aliyah (MA) institutions in Depok City, all of which are still private. 15 of $28 \mathrm{MA}$ are in Islamic boarding schools that do not allow using smartphones. Still, some MA allow students to bring smartphones to Madrasah, for instance, MA Al-Islamiyah Depok City.

The MA Al-Islamiyah policy allows students to bring handphones into the classroom because some teachers sometimes need handphones as interactive learning media to find teaching materials and others. According to the Principal of MA AlIslamiyah;

"It is undeniable that the Internet is needed not
ultimately to ban it because it aims to control
the students. Sometimes parents also ask
specifically not to be banned, because when
their sons and daughters are late, or there is a
sudden change in the learning process at
school, they can immediately contact them at
home (The Principal of MA Al-Islamiyah,
interview, on 13 February 2019 in MA Al-
Islamiyah, Depok City).

In addition, handphones are also used to help students find references through the Internet because several subjects often use the Internet, such as mathematics, history, biology, physics, and economics.

The intensity of internet use on MA Al-Islamiyah students is measured to determine their activities in accessing the Internet, both at school and home, their frequency of accessing the Internet every day, various applications, or other features they usually access. Figure 1 below presents the frequency of the respondents accessing the Internet in one day. Most of the respondents access the Internet no more than 6 hours in one day. The respondents who access the Internet for less than 1 hour are 16\% (40 students), while the respondents who access the Internet for 1 to 3 hours are $29 \%$ ( 72 students). The respondents who access the Internet for 4 to 6 hours are $28 \%$ ( 68 students). The respondents who access the Internet for 7 to 9 hours are $13 \%$ (32 students), and the respondents who access the Internet for more than 9 hours are 14\% (34 students).

Smartphone electronic devices are the most widely used by the respondents $(81 \%)$. However, students also use other devices such as laptops (13\%), computers (3\%), and mobile phones $(2 \%)$ that are not connected to the Internet. The ownership of electronic devices that are often used by students, around $92 \%$ are privately owned, the remaining $8 \%$ are owned by their parents and relatives.

Internet services that are frequently accessed by MA Islamiyah students in the past month are social media $(72 \%)$, religious content $(35 \%)$, games $(26 \%)$, listening to music $(15 \%)$, watching movies $(12 \%)$, online tutorials (7\%), and pornography (1\%). Furthermore, 37\% of students answer that the purpose of accessing the Internet is for learning, information seeking, entertainment, and communication. Meanwhile, 2\% of those who only use the Internet for learning, 15\% answer for information seeking, and $6 \%$ of respondents say surfing the Internet is for entertainment only.

Figure 1. Frequency of internet access in a day

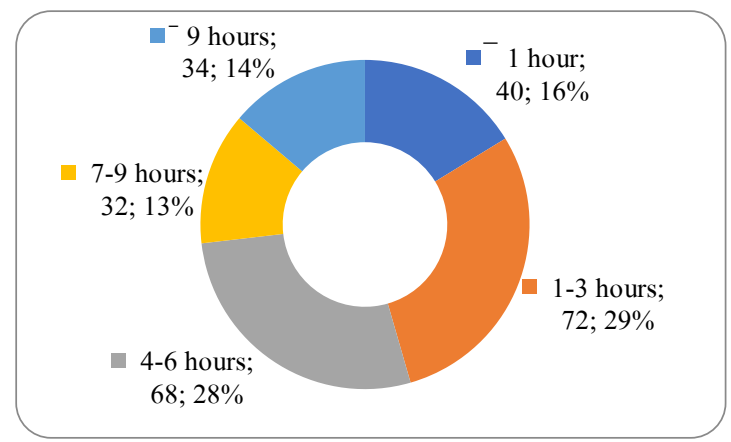

\section{Use of Social Media}

Figure 1. below presents various social media applications that are often used by the respondents. The social media most frequently accessed by MA Al-Islamiyah students is WhatsApp. They use this application to communicate with parents, friends, and relatives and communicate in 
doing school assignments, then IG (Instagram) and YouTube. The application that MA Al-Islamiyah students most minor use is Twitter. This application is indeed segmented for adult internet users and is very rarely used by school students or teenagers.

Figure 2 Most Accessed Social Media

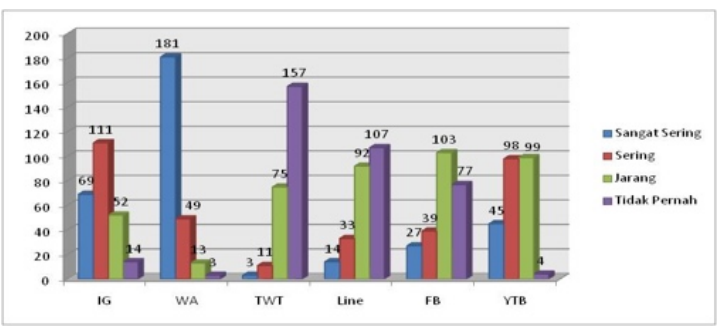

\section{Access to School Subjects}

The MA Al-Islamiyah policy allows students to bring smartphones into the classroom because many school subjects use the internet as an interactive learning medium to find teaching materials and help students find references through the internet, such as mathematics, history, biology, physics and economics. This policy is also implemented because today is the era of information and communication technology, so there is no need to limit it. As the Principal of Madrasah said:

The current digital era cannot be denied, the existence of the internet helps the learning process. I belong to the category that supports the use of information and computer technology (ICT) in the teaching and learning process (The Principal of MA Al-Islamiyah, interview, on 13 February 2019 in MA Al-Islamiyah, Depok City)

Madrasah only encourages students not to activate smartphones unless teaching and learning activities require using a smartphone. Since it is a recommendation, some students activate smartphones to access social media, listen to music, or other feat ures.

The Impact of the Internet on the Psychological Condition of Students

\section{Cannot be separated from the smartphone (wake up immediately looking for a smartphone)}

The tendency of students to be inseparable from smartphones is also checked through the question, "how do you feel if you do not use a smartphone for one day?". There are $29 \%$ of students who answer "uncomfortable" and $69 \%$ of students who answer "normal". Although the Internet and its various supporting devices have become a kind of daily necessity today, these things have not yet become a part that affects the daily life of MA Islamiyah students. When asked which is better, whether they left their wallet or smartphone behind, $52 \%$ of respondents answer that it is better to leave behind a smartphone, while those who answer otherwise are $48 \%$. Even when asked what activities they do when they wake up, only $38 \%$ of respondents admit that they immediately check their smartphones, while $62 \%$ of other respondents do other activities. When they wake up, a few students directly access smartphones because some students do not have their own smartphones, but they borrow from their parents. In addition, some students live in Islamic boarding schools where using smartphones is not allowed. The result of interviews with five students who often come late to the Madrasah is they are often late because they sleep late playing online games. The games that are currently the favorites of male students are PUBG and Mobile Legend. PUBG is popular because they play with friends in a team so that they can play together.

Students' addiction to the Internet is also seen from their preoccupation with online making them lazy to do other activities such as playing with their peers, forgetting their duties and responsibilities, particularly studying. Also, when studying in class, some students use smartphones for social media and listening to music.

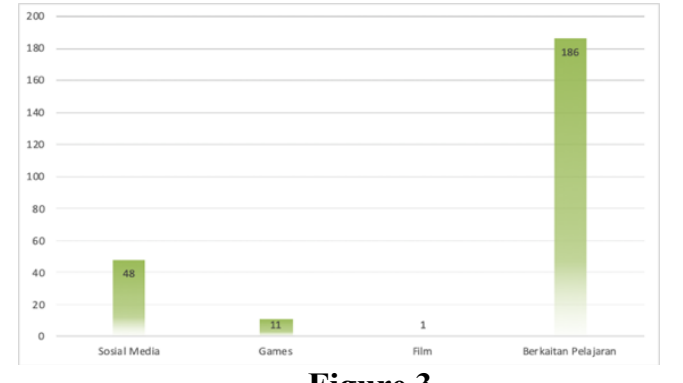

Figure 3

Frequently Accessed Internet Features in Class

The figure above explains that $86 \%$ of respondents (186 students) access the internet features related to lessons because many subjects (Mathematics, History, Biology, Physics, and Economics) use the Internet to search for materials related to these subjects. 
However, some students access the Internet for other aims, as admitted by $20 \%$ of respondents (48 students) who often access social media. $4 \%$ of respondents (11 students) access games, and 1 respondent watches movies in class. This is in line with the Vice Principal of Student Affairs who said that the violations committed by students are related to the Internet during teaching and learning activities, including social media and listening to music (Interview with the Vice Principal of Student Affairs of MA Al-Islamiyah on 13 February 2019 in MA Al-Islamiyah, Depok City).

\section{Restless if the Quota Runs Out (hurry up to buy)}

The importance of internet access for MA Al-Islamiyah students is illustrated in Figure 4 . below. They will immediately buy internet credit if their internet quota runs out. $54 \%$ of respondents (132 students) say that they would directly purchase internet quota if their data package ran out, $23 \%$ of respondents (56 students) asked friends for help to share their quota. Only $4 \%$ of respondents (10 students) rely on the $\mathrm{WiFi}$ network to access the Internet. Meanwhile, $20 \%$ of respondents (48 students) did nothing when their internet data package ran out.

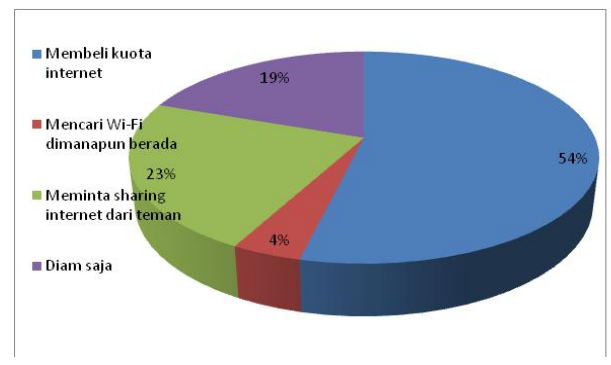

Figure 4: Things to do when students run out of internet quota

Another interesting point is the costs incurred by students to buy internet quota every month. $33 \%$ of respondents (81 students) spend an average of Rp. 50.000,- to Rp. 100.000,-. While $4 \%$ of respondents (10 students) spend more than Rp. 100.000,- per month and $57 \%$ of respondents (139 students) spend less than Rp. 50.000,. Students buy internet quota from their daily allowance because Madrasah does not facilitate internet for students. The internet facilities at MA Islamiyah are only intended for Madrasah's administration, with strength is only 10 MBPS (Interview with a student at MA AlIslamiyah on 13 February 2019 in MA AlIslamiyah, Depok City).

\section{As part of Everyday Media (Shopping, Studying, Communication)}

In addition to social media, MA Islamiyah students also use the internet to access multiples websites for learning, entertainment, online shopping, and playing games. The following are various feat ures that have been accessed by MA Al-Islamiyah students in the past month;

a. Brainly (a website and application which can help students complete homework and allow users to ask and answer questions related to lessons at school openly to other users)

b. Games (free fire, mobile legends, PUGB, Arena of Valor), students like to play PUGB games because of survival and challenging

c. Youtube (watching religious lectures, such as ustadz Abdul Somad, ustazd Adi Hidayat, Khalid Basalamah, and Habib Bahar)

d. Watching anime, horror stories nosleep, glass screen 21, music, Korean drama (VIU), samehadaku, (online anime sites equipped with Indonesian subtitles, such as Naruto, Baruto, Dragon Ball and others), pinterest, u-dictionary, and guitar cords

e. Kaskus is used to search for information and knowledge, join new communities, buy and sell all kinds of goods and services at the best prices.

\section{Strategy for Handling Student Addiction on the Internet}

\section{Madrasah Regulations}

Although students are allowed to bring smartphones into the classroom, a policy regulates sanctions as one of the student coaching strategies. If students activate their smartphones during teaching and learning activities, they will be subject to an error point of 20. The Vice Principal for Student Affairs instructs all teachers to confiscate students' smartphones if they are seen opening YouTube, for example, during the teaching and learning process. The teacher immediately takes their smartphones. 
As explained above, there are still $20 \%$ of respondents (48 students) who often access social media, $4 \%$ of respondents (11 students) who access games, and 1 respondent who admits to watching movies during teaching and learning activities in class. The Principal of the MA says that there has never been a raid on smartphones owned by students. Every Friday and Monday, the school always reminds students about the positive and negative impacts of the Internet and encourages using the Internet positively. Thus, all this time, teachers only think positively that students use their smartphones for positive activities. Moreover, the current digital era cannot be denied. The Internet helps in the learning process. The Principal of MA Al-Islamiyah belong to the category that supports the use of ICT (information and computer technology) in the teaching and learning process (Interview with the Principal of MA Al-Islamiyah on 13 February 2019 in MA Al-Islamiyah, Depok City)

Although punishment has been implemented for students who use smartphones during the teaching and learning process, Madrasah's control over smartphones has not been effective. It can be seen from the relatively large number of smartphone confiscations in one school year. This means that the deterrent effect that is the goal of punishment, has not significantly affected students. In some cases, students whose smartphones have been confiscated can continue to use smartphones by lending them to their friends.

\section{Family Policy}

In addition to Madrasah, students also use electronic devices at home. Smartphones are devices whose use is most permitted at any time as long as students are at home. A total of 213 students claim to use smartphones at any time while they are at home. There are 46 students who have a WiFi (Wireless Fidelity) network. There are 29 of 46 students who admit that they are free to access the network at any time, while 17 students say their parents place restrictions on accessing the Wi-Fi network at home. The results of an interview with one of the students who have a Wi-Fi network at home says that he is free to use the Internet without any rules from his parents. Also, his parents never control any applications on his smartphone. However, some parents only allowed their children to use Wi-Fi during holidays, and only at certain hours such as 5 pm until maghrib prayers (Interview with a student at MA Al-Islamiyah on 27 February 2019 in MA Al-Islamiyah, Depok City).

At the beginning of the year, the Madrasah socialized to parents and students about using the Internet in Madrasah (Interview with a student at MA Al-Islamiyah on 27 February 2019 in MA Al-Islamiyah, Depok City). Because apart from at school, students also access the Internet at home, parents must also control their children in using the Internet at home. There must be cooperation between parents and Madrasah in directing, educating, and supervising children's behaviour and internet use. There needs to be a synergy between parents and Madrasah. When the child is at home, the supervisory task is with the parents, while when the child is at school, the supervisory task is the school's responsibility (principal, teachers, and all elements in the school). Parents should limit the use of smartphones at home and forbid their children to view specific sites to maintain their children's morale.

Meetings with parents of students in the new school year explain that parents should supervise their children when using smartphones at home because many negative factors occur due to internet addiction today. In addition, children should be directed to do positive activities such as attending Al-Qur'an recitations in their neighbourhood (Interview with the Vice Principal of Student Affairs of MA Al-Islamiyah on 13 February 2019 in MA Al-Islamiyah, Depok City).

The results of this study are that students' life patterns have indeed become part of the presence of technology. The intensity of smartphone relationships with students becomes higher, including always ensuring the availability of online facilities and psychological disorders experienced by someone when his smartphone does not work. As stated by Ciman \& Wac, that the relationship between humans and mobile phones has triggered stress among users, which can interfere with one's awareness and activities (Ciman \& Wac, 2016).

Basically, the Internet has many benefits for students if it aims to help learning activities and find information about learning. However, there must be strict supervision or 
control from parents and Madrasah. Families should direct their children about the meaning of internet use, such as the content on the Internet that is allowed to be accessed. The Internet helps the world of education to develop a more conducive and interactive teaching and learning situation. The use of the Internet, which contains all information, requires its users to be wise in responding to it, especially negative information. The role of parents and teachers to assist is essential to protect students not falling into the harmful effects of internet use (Sriyono, 2018). In addition, excessive and uncontrolled internet use can cause internet addiction (Yustiana, 2018).

The IDN Times (2019) survey found that the highest percentage $(45 \%)$ of millennials are heavy users, with internet consumption reaching 4-6 hours per day. In line with this, as revealed in the research findings, $28 \%$ of MA Al Islamiyah students use the Internet for 4-6 hours a day, which means that they are heavy users. Then IDN Times also categorizes internet consumption that is more than 7 hours a day as addicted users. Based on this category, $27 \%$ of MA Al Islamiyah students are categorized into internet addiction.

\section{CLOSING}

The intensity of accessing the Internet for MA Islamiyah students in Depok City varies. This intensity is measured by the duration they access the Internet every day. Most students access the Internet for no more than 6 hours per day. Apart from Madrasah, students also use electronic devices at home. The tendency of internet addiction is experienced by $13 \%$ of respondents who access the Internet for 7 to 9 hours and $4 \%$ of respondents who access the Internet for more than 9 hours a day.

The impacts of the Internet on the students' psychology are they cannot be separated from a smartphone (waking up immediately looking for a smartphone) and feel uncomfortable when not connected to the Internet. Also, online preoccupation makes them lazy to do other activities such as playing with their peers, forgetting their duties and responsibilities, particularly studying. While studying in class, some students use their smartphones for social media and listening to music.

Madrasah allows students to bring smartphones into class, but a policy regulates sanctions as one of the student coaching strategies. If students activate their smartphones during teaching and learning activities, they will be subject to error points of 20 and smartphone confiscation. However, it has not been effective because there are still $20 \%$ of respondents (48 students) who access social media, $4 \%$ of respondents (11 students) who access games, and 1 respondent who claims to watch movies during teaching and learning activities in the classroom.

\section{ACKNOWLEDGEMENT}

The authors would like to thank all those who contributed to this research. Head of the Jakarta Religious Research and Development Center, who gave the author the opportunity to conduct this research. MA Islamiyah Depok, which is the target of this research. Especially for all editors of the journal Al Qalam

\section{REFERENCES}

Asosiasi Penyelenggara Jasa Internet Indonesia. (2017). Infografis: Penetrasi dan Perilaku Pengguna Internet Indonesia.

Alatas, S. (2014). Dampak konvergensi media terhadap akulturasi budaya lokal. Tersedia: http://www. academia. edu/6171985/Dampak

Konvergensi_Media_Terhadap_Akultu rasi Budaya_Lokal.[20 Nov. 2014].

Arintina, I., \& Yarti, R. N. (2019). Menumbuhkembangkan Human Digital Skill Pendidik Di Abad Ke 21. In Prosiding Seminar Nasional Program Pascasarjana.

Anggraeni, Mufidatu Lila, et al. (2016). Hubungan Antara Self Kontrol Dan Internet Addiction Disorder Pada Mahasiswa Jurusan Teknologi Pendidikan Anggatan Universitas Negeri Malang

IDN Times. (2019). Generasi Eksplorasi. Jakarta: KPG. 
Bastian, B., Jetten, J., \& Radke, H. R. (2012). Cyber-dehumanization: Violent video game play diminishes our humanity. Journal of Experimental Social Psychology, 48(2), 486-491.

Indra, Cynthia Magdalena, et al (2019). Hubungan Kecanduan Internet Dengan Depresi Pada Pelajar Kelas XI di SMA Negeri 9 Binsus manado Tahun Ajaran 2018/2019. Jurnal Medika dan Rehabilitas (JMR), volume 1 Nomor 3

IDN Times. (2019). Generasi Eksplorasi. Jakarta: KPG.

Kellner, D. (1995). Intellectuals and new technologies. Media, Culture \& Society, 17(3), 427-448.

Lenţa, O. E., \& Cormoş, V. C. (2014). Social Division And Symbolic Violence In The Digital Era. European Journal of Science and Theology, 10(4), 69-78.

Melissa, E. (2010). Budaya Digital Dan Perubahan Konsumsi Media Masyarakat.

Motschnig-Pitrik, R., \& Holzinger, A. (2002). Student-centered teaching meets new media: Concept and case study. Educational Technology \& Society, 5(4), 160-172.

Nurkinan. (2017). Dampak Media Online Terhadap Perkembangan Media Konvensional. Jurnal Politikom Indonesiana. Vol. 2 No. 2

Ngafifi, M. (2014). Kemajuan teknologi dan pola hidup manusia dalam perspektif sosial budaya. Jurnal Pembangunan Pendidikan: Fondasi dan Aplikasi, 2(1).

Palupi, Y., \& Wates, P. P. I. P. (2015). Digital parenting Sebagai Wahana Terapi Untuk Menyeimbangkan Dunia Digital Dengan Dunia Nyata Bagi Anak

Painter, J., Kristiansen, S., \& Schäfer, M. S. (2018). How "Digital-born" media cover climate change in comparison to legacy media: A case study of the COP 21 summit in Paris. Global Environmental Change, 48, 1-10.

Pawito. (2014). Meneliti Ideologi Media : Catatan Singkat. Jurnal Komunikasi PROFETIK. Vol. 7. No. 1. Universitas Sebelas Maret Surakarta

Pratt, A. C. (2000). New media, the new economy and new spaces. Geoforum, 31(4), 425-436.
Setianingsih, Amila Wahyuni, A., \& Firiana Noor, K. (2018). Dampak Penggunaan Gadget Pada Anak Usia Prasekolah. Gaster.

Setianingsih, S. (2018). Dampak Penggunaan Gadget Pada Anak Usia Prasekolah dapat meningkatkan Resiko Gangguan Pemusatan Perhatian dan Hiperaktivitas. Gaster, Jurnal Ilmu Kesehatan. https://doi.org/10.30787/gaster.v16i2.2 97

Sriyono, S. (2018). Internet Sebagai Media Pembelajaran. Prosiding Seminar Nasional Pendidikan KALUNI.

Septiarti, S. W. (2017). Bab III Pendidikan Ditinjau Dari Perspektif Antropologi. Sosiologi Dan Antropologi Pendidikan, 71.

Setyawan, S. 2019. Mengajar Digital Natives: Tantangan bagi Dunia Pendidikan. Academia.Edu

Supratman, L. P. (2018). Penggunaan Media Sosial oleh Digital Native.

Situmorang, J. R. (2012). Pemanfaatan internet sebagai new media dalam bidang politik, bisnis, pendidikan dan sosial budaya. Jurnal Administrasi Bisnis, 8(1).

Tyas, Fany Lukinaning. (2016). Hubungan Antara Adiksi Internet (Internet Addiction) Dengan Kecerdasan emosi Pada Remaja Di SMP Negeri 05 Yogyakarta. Universitas Muhammadiyah Yogyakarta.

Wijaya, E. Y., Sudjimat, D. A., Nyoto, A., \& Malang, U. N. (2016). Transformasi pendidikan abad 21 sebagai tuntutan pengembangan sumber daya manusia di era global. In Prosiding Seminar Nasional Pendidikan Matematika (Vol. 1, No. 26, pp. 263-278).

Wuryantai, A. E. W. (2004). Digitalisasi masyarakat: Menilik kekuatan dan kelemahan dinamika era informasi digital dan masyarakat informasi.

Yustiana, A. V. (2018). Hubungan Adiksi Internet Dengan masalah Emosi dan Perilaku Siswa-Siswi Sekolah Menengah Atas Swasta Di Kota Denpasar.https://doi.org/10.1017/CBO 9781107415324.004 